\title{
The Effect of Price and Service Quality on Customer Satisfaction of PT Huda Express Courier Services at Mcdonald's Bintaro Restaurant
}

\author{
Putri Nilam Kencana \\ Universitas Pamulang \\ E-mail: dosen01877@unpam.ac.id
}

\begin{abstract}
Customer satisfaction is the main aspect that must be met by the company, with the creation of customer satisfaction, demand will also rise. This study aims to determine the effect of price and service quality on customer satisfaction PT. Huda Express at McDonald's Bintaro Restaurant. The method used is a quantitative method with an associative approach, with 100 respondents. Statistical tests using multiple regression analysis, coefficient of determination, and hypothesis testing with $\mathrm{t}$ test and $\mathrm{F}$ test. The results of the study, showed that price and service quality have a positive effect on customer satisfaction with the regression equation $\mathrm{Y}=2,279+0,307 \mathrm{X}_{1}+0,130 \mathrm{X}_{2}$. Price contributed $62.5 \%$ to customer satisfaction, while service quality contributed $59.6 \%$ to customer satisfaction. From testing hypotheses using statistical tests Fcount $>\mathrm{F}$ table or $(163.410>3.09)$, this is also strengthened with a probability of $0,000<0.05$. Thus $\mathrm{H} 0$ is rejected and H1 is accepted. This means that there is a positive and significant effect simultaneously between price and quality of service on customer satisfaction.
\end{abstract}

Keywords: Price, service quality, customer satisfaction

\section{INTRODUCTION}

The development of the business world that is increasing today demands good management so that a company can still run its business. This is because of the large number of companies that are expanding in the shipping field. Not only private companies, but Pos Indonesia as a state-owned company also participated in improving itself and implementing a number of facilities in the delivery of goods. This is due to the high level of competition that occurs between shipping companies in Indonesia.

The more business people in the same field, of course there will be more choices for potential consumers (Daraba, Subianto, \& Salam, 2018; Sofyan, Haris, Akib, Gani, \& Nuralim, 2018; Syam , Lamangida, Madubun, \& Akib, 2018). Things like this also happen in the field of shipping goods, because now there are many companies providing freight forwarding services that can be accessed easily by the wider community. Different levels of service and also tariffs will certainly be a special consideration for users of shipping services, where everyone will expect the best service with a number of affordable and pocket-friendly payments (Agustina, 2015; Japarianto, 2018; Laurence \& Mustamu, 2015).

In the business of shipping goods, punctuality is also one of the factors that has a strong influence on the success of an shipping company (Grönroos, 1994; Philip Kotler, 2000; Lovelock, Wirtz, 2013; Sutisna, 2003). Customers always expect their shipments to arrive on time and according to the estimated schedule from the start, this is a special concern for customers, especially those who do have a number of business interests related to the items they 


\author{
30 Jurnal Administrare: Jurnal Pemikiran Ilmiah dan Pendidikan Administrasi Perkantoran \\ Vol. 7, No. 1, January-June 2020, Pages 29-38
}

send. The process of sending goods or products is very often done by the wider community and the process also takes place very quickly. This is because people who want or need delivery services for goods or products for practical needs, especially in food courier services which have adapted to the business world with application technology, compete with similar competitors, and require good prices and services to create satisfaction customer.

Price is a value that is made to be a benchmark value of goods or services. Price according to (Kotler and Armstrong, 2008) is the amount of money exchanged for a product or service. Furthermore, price is the sum of all values that consumers exchange for the amount of benefit by owning or using an item or service. Quality of service provides an encouragement to customers to establish strong bonds with the company. According to (Tjiptono \& Chandra, 2011), service quality is a presentation of a product or service according to the size applicable at the place where the product is held and the delivery is at least the same as desired and expected by consumers.

According to (P. Kotler \& Keller, 2009) customer satisfaction is the result felt by buyers who experience the performance of a company in accordance with their expectations. Customers are satisfied when their expectations are met, and feel very happy when their expectations are exceeded. Satisfied customers tend to stay loyal longer, buy more, are less sensitive to price changes and their talks benefit the company (Irawan \& Japarianto, 2013; Nasir, Faiz, \& Lee, 2011; Rasyid, 2017; Safitri, Rahayu, \& Indrawati, 2016 ).

\title{
METHOD
}

The company which is the object of this research is PT. Huda Express with the address of the head office on Jalan Raya Kebayoran Lama, RT.1 / RW.2, North Sukabumi, Kebon Jeruk District, West Jakarta City, Special Capital Region of Jakarta. In this study, the population is customers who use the services of PT Huda Express to McDonald's Bintaro with 4,980 customers. By using the Slovin formula, the number of samples used in this study was 100 customers.

\section{RESULT AND DISCUSSION}

Customer satisfaction is the main aspect that must be met by the company, with the creation of customer satisfaction, the demand will. One of the things that causes customer satisfaction is in terms of price and quality of services provided. Price and quality of services provided must be able to satisfy consumers. Consumers can be satisfied with a service if they have expectations can be fulfilled. Consumers also compare what is obtained in a company with other companies. So the presence of competitors is important to improve the quality of service of a company.

\section{Characteristics of Respondents}

With a sample of 100 people, the questionnaire was distributed to users of PT Huda Express courier services who made purchases on delivery at McDonald's Bintaro. Respondent data according to the results of the questionnaire distributed by age as follows: 


\section{Table 1}

\section{Data of Respondents by Age}

\begin{tabular}{|c|c|c|c|}
\hline No & Age (Years) & Amount & Presentage (\%) \\
\hline 1 & $20-30$ & 53 & 51.0 \\
\hline 2 & $31-40$ & 33 & 31.7 \\
\hline 3 & $41-50$ & 12 & 11.5 \\
\hline 4 & $>51$ & 2 & 1.9 \\
\hline & Amount & 100 & 100 \\
\hline
\end{tabular}

Source: Primary data processed

Table 1 shows that the percentage of customers by age with the most samples is those aged $\geq 20-30$ years which is $51 \%$ ( 53 people), then $31-40$ years by $31.7 \%$ (33 people), $41-50$ years by $11.5 \%$ ( 12 people), and the least of which is 51 years at $1.9 \%$ ( 2 people). Respondent data according to the results of the questionnaire distributed by sex in table 2 .

Table 2

Respondent Data Based on Gender

\begin{tabular}{|l|c|c|r|}
\hline No & Gender (Years) & Amount & Presentage (\%) \\
\hline 1 & Male & 71 & 63.3 \\
\hline 2 & Famale & 29 & 27.9 \\
\hline \multicolumn{2}{|c|}{ Amount } & 100 & 100 \\
\hline
\end{tabular}

From the table above shows that the percentage of customers by sex is male by $68.3 \%$ (71 people), while for female gender is $27.9 \%$ (29 people). Respondent data according to the results of the questionnaire distributed based on length of work as follows:

Table 3

Length of working

\begin{tabular}{|l|c|c|r|}
\hline No & years of service (Years) & Amount & Presentage (\%) \\
\hline 1 & $0-5$ & 12 & 11.5 \\
\hline 2 & $6-10$ & 66 & 63.5 \\
\hline 3 & $11-20$ & 22 & 21.2 \\
\hline 4 & $>20$ & 0 & 0 \\
\hline & Amount & 100 & 100 \\
\hline
\end{tabular}

Source: Primary data processed

From table 3, shows that the percentage of customers obtained by the level of work time. The length of work period is $0-5$ years, 12 people (11.5\%), then 6-10 years, 66 people $(63.5 \%)$, at the level of 11-20 years, 22 people (21.2\%). Respondent data according to the results of the questionnaire distributed by level of education as follows: 
32 | Jurnal Administrare: Jurnal Pemikiran Ilmiah dan Pendidikan Administrasi Perkantoran Vol. 7, No. 1, January-June 2020, Pages 29-38

\section{Table 4}

Respondent Data Based on Education

\begin{tabular}{|l|l|c|r|}
\hline No & \multicolumn{1}{|c|}{ Educational } & Amount & Presentage (\%) \\
\hline 1 & Senior High School & 44 & 42 \\
\hline 2 & Diploma (D III) & 8 & 7.7 \\
\hline 3 & Bachelor (S1) & 46 & 44.2 \\
\hline 4 & Master's program (S2) & 2 & 1.9 \\
\hline 5 & Doctoral program (s3) & 0 & 0 \\
\hline \multicolumn{2}{|c|}{ Amount } & 100 & 100 \\
\hline
\end{tabular}

Source : Primary data processed

From the table above shows that the percentage of customers based on education with the highest sample obtained by high school education is $42.3 \%$ (44 people), then D3 education gets a percentage of $7.7 \%$ (8 people), S1 education with a percentage of $44.2 \%$ (46 people), and S2 education earned a percentage of $1.9 \%$ ( 2 people).

\section{Correlation Coefficient Analysis}

Table 5

Price Correlation Coefficient Analysis on Customer Satisfaction

\section{Correlations $^{\mathrm{b}}$}

\begin{tabular}{llr|r}
\hline \multicolumn{1}{c}{ Correlations $^{\mathbf{b}}$} & Price & \multicolumn{1}{c}{ Satisfaction } \\
\hline Price & Pearson Correlation & 1 & $.791^{* *}$ \\
\cline { 2 - 4 } & Sig. (2-tailed) & 100 & .000 \\
\cline { 2 - 4 } & $\mathrm{N}$ & $.791^{* *}$ & 100 \\
\hline Satisfaction & Pearson Correlation & .000 & 1 \\
\cline { 2 - 4 } & Sig. (2-tailed) & 100 & \\
\cline { 2 - 5 } & $\mathrm{N}$ & &
\end{tabular}

**. Correlation is significant at the 0.01 level (2-tailed).

Source: Primary data processed, 2018

From the table above, it can be seen that the correlation coefficient is rxy $=0.791$ or rxy $>$ 0 , then there is a strong positive influence between price on customer satisfaction. Based on the calculation of correlation of 0.791 , it can be seen from the table above included in the interval 0.60-0.799 with a strong influence level. 
Table 6

Correlation Coefficient Analysis of Service Quality to Price Correlations $^{\mathrm{b}}$

\begin{tabular}{llr|r}
\hline \multicolumn{2}{c}{ Correlations $^{\text {S }}$} & Service Quality & \multicolumn{1}{c}{ Satisfaction } \\
\hline Service Quality & Pearson Correlation & 1 & $.772^{* *}$ \\
\cline { 2 - 4 } & Sig. (2-tailed) & 100 & .000 \\
\cline { 2 - 4 } & $\mathrm{N}$ & $.772^{* *}$ & 100 \\
\hline Satisfaction & Pearson Correlation & .000 & 1 \\
\cline { 2 - 4 } & Sig. (2-tailed) & 100 & 100 \\
\cline { 2 - 4 } & $\mathrm{N}$ & & \\
\hline
\end{tabular}

**. Correlation is significant at the 0.01 level (2-tailed).

Source: Primary data processed, 2018

From the table above, it can be seen that the correlation coefficient of rxy $=0.722$ or rxy> 0 , then there is a strong positive influence between service quality on customer satisfaction. Based on the calculation of the correlation of 0.722 , it can be seen from the table above, including the 0.60-0.799 interval with a strong influence level.

\section{Multiple Linear Regression Test}

In analyzing the price factor $\left(\mathrm{X}_{1}\right)$ and service quality $\left(\mathrm{X}_{2}\right)$ to customer satisfaction $(\mathrm{Y})$, regression analysis using :

\section{Table 7}

Multiple Linear Regression Analysis

Coefficients $^{\text {a }}$

\begin{tabular}{|c|c|c|c|c|c|}
\hline \multirow[b]{2}{*}{ Model } & \multicolumn{2}{|c|}{$\begin{array}{c}\text { Unstandardized } \\
\text { Coefficients }\end{array}$} & \multirow{2}{*}{$\begin{array}{c}\text { Standardized } \\
\text { Coefficients } \\
\text { Beta }\end{array}$} & \multirow[b]{2}{*}{$\mathrm{t}$} & \multirow[b]{2}{*}{ Sig. } \\
\hline & B & Std. Error & & & \\
\hline (Constant) & 2,279 & 652 & & 3,498 & .001 \\
\hline Price & .307 & .86 & .509 & 3,564 & .001 \\
\hline Service Quality & 130 & .060 & .311 & 2,177 & .032 \\
\hline
\end{tabular}

a. Dependent Variable: customer satisfaction

Based on the table, it can be concluded that $\mathrm{X}_{1}=0.307$ and $\mathrm{X}_{2}=0.130$ obtained the regression equation model is $\mathrm{Y}=2,279+0,307 \mathrm{X}_{1}+0,130 \mathrm{X}_{2}$

A constant of 2,279 means that if the price and service quality is considered constant, then customer satisfaction is 2,279 points. Regression coefficient $X_{1}$ of 0.307 means that if the price value increases reasonably by 1 (one) point while the service quality is assumed to be constant, it will cause an increase in customer satisfaction of 0.307. Regression coefficient $\mathrm{X}_{2}$ of 
34 | Jurnal Administrare: Jurnal Pemikiran Ilmiah dan Pendidikan Administrasi Perkantoran Vol. 7, No. 1, January-June 2020, Pages 29-38

0.130 means that if the value of service quality has increased by 1 (one) point while the price is assumed to be constant, it will cause an increase in customer satisfaction of 0.130 . .

\section{Analysis of the Coefficient of Determination}

The value used in determination is to use the $\mathrm{R}$ Square value is used to measure how much the model's ability to explain the dependent variable. The $\mathrm{R}$ Square value used is taken from the Model Summary table.

Table 8

Price Determination Coefficient on Customer Satisfaction

\section{Coefficients $^{\text {a }}$}

\begin{tabular}{|c|c|c|c|c|c|}
\hline \multirow[b]{2}{*}{ Model } & \multicolumn{2}{|c|}{$\begin{array}{l}\text { Unstandardized } \\
\text { Coefficients }\end{array}$} & \multirow{2}{*}{$\begin{array}{c}\text { Standardized } \\
\text { Coefficients } \\
\text { Beta } \\
\end{array}$} & \multirow[b]{2}{*}{$\mathrm{t}$} & \multirow[b]{2}{*}{ Sig. } \\
\hline & $\mathrm{B}$ & Std. Error & & & \\
\hline (Constant) & 2.279 & .652 & & 3.498 & .001 \\
\hline Price & .307 & .086 & .509 & 3.564 & .001 \\
\hline Service Quality & .130 & .060 & .311 & 2.177 & .032 \\
\hline
\end{tabular}

a. Dependent Variable: customer satisfaction

From the table above can be seen Adjusted R Square of 0.625 or of $62.5 \%$. This means that variations in price independent variables can explain the dependent variable customer satisfaction by $62.5 \%$.

Table 9

Determination coefficient of service quality to Customer Satisfaction

Model Summary

\begin{tabular}{|r|r|r|r|}
\hline R & \multicolumn{1}{|c|}{ R Square } & Adjusted R Square & Std Error of the Estimate \\
\hline $.772^{*}$ & .596 & .592 & 2.27442 \\
\hline
\end{tabular}

Source: Primary data processed, 2018

From the table above can be seen Adjusted R Square of 0.596 or of $59.6 \%$. This means that variations in the independent variable service quality can explain the dependent variable customer satisfaction by $59.6 \%$. 
Table 10

Price Determination Coefficient and Service Quality on Customer Satisfaction Model Summary

\begin{tabular}{|r|r|r|r|r|}
\hline Model & R & R Square & \multicolumn{1}{|c|}{$\begin{array}{c}\text { Adjusted R } \\
\text { Square }\end{array}$} & $\begin{array}{c}\text { Std Error of the } \\
\text { Estimate }\end{array}$ \\
\hline 1 & $.791^{*}$ & .625 & .621 & 2.19031 \\
\hline 2 & $.802^{*}$ & .643 & .635 & 2.14971 \\
\hline
\end{tabular}

a. Predictors: (Constant), Price

b. Predictors: (Constant), Price, Service Quality

Source: Primary data processed, 2018

From the table above can be seen Adjusted R Square of 0.652 or $65.2 \%$. This means that variations in the price independent variable can explain the dependent variable customer satisfaction by $65.2 \%$, and seen Adjusted R Square service quality of 0.643 or $64.3 \%$. This means that variations in the independent variable service quality can explain the dependent variable customer satisfaction by $64.3 \%$.

\section{Simultaneous Test}

It is known that the table's $F$ value is 3.09. Because the value of $F_{\text {Count }} 163.410$ is greater than the value of $F_{\text {table }} 3.09$, or $\mathrm{F}_{\text {Count }}>\mathrm{F}_{\text {table }}$ or $163.410>3.09$, it can be concluded that the price and quality of service simultaneously affect customer satisfaction.

\section{CONCLUSION}

From the results of gathering opinions through a questionnaire distributed to 100 respondents, the price variable contributed to customer satisfaction by $62.5 \%$ and, $t_{\text {Count }}$ $(3,564)>t_{\text {table }}(1,662)$. $Y$ regression test results $=2.672+0.477 \mathrm{X}$ it shows that the price variable has a positive influence on customer satisfaction, meaning that every time there is an increase in a reasonable variable price will also increase customer satisfaction. Service quality variables contributed to customer satisfaction by $59.6 \%$ and, $t_{\text {Count }}(2.177)>t_{\text {table }}(1.662)$. From the results of the regression test $\mathrm{Y}=2.587+0.322 \mathrm{X}$ it shows that the service quality variable has a positive influence on customer satisfaction, meaning that every time there is an increase in a reasonable price variable it will also increase customer satisfaction. Value of $F_{\text {count }}>F_{\text {table }}$ or $163.410>3.09$, it can be concluded that the price and quality of service simultaneously affect customer satisfaction.

\section{REFERENCES}

Agustina, C. (2015). Sistem Informasi Perusahaan Ekspedisi Muatan Kapal Laut Pada PT. Tirang Jaya Samudera Semarang. Jurnal Bianglala Informatika.

Daraba, D., Subianto, A. B., \& Salam, R. (2018). An effort to Improve the Quality of Workers at the Makassar city Department of Employment Services. Jurnal Ilmiah Ilmu 
36 Jurnal Administrare: Jurnal Pemikiran Ilmiah dan Pendidikan Administrasi Perkantoran Vol. 7, No. 1, January-June 2020, Pages 29-38

Administrasi Publik, 8(1), 21-26.

Grönroos, C. (1994). From Marketing Mix to Relationship Marketing. Management Decision. https://doi.org/10.1108/00251749410054774

Irawan, D., \& Japarianto, E. (2013). Analisa Pengaruh Kualitas Produk Terhadap Loyalitas Melalui Kepuasan Sebagai Variabel Intervening Pada Pelanggan Restoran Por Kee Surabaya. Jurnal Manajemen Pemasaran.

Japarianto, E. (2018). Pengaruh Logistics Service Quality terhadap Customer Retention dengan Customer Satisfaction sebagai Variabel Intervening pada Industri Ekspedisi Laut Di Surabaya. Jurnal Manajemen Pemasaran. https://doi.org/10.9744/pemasaran.12.1.25

Kotler dan Amstrong. (2008). Prinsip-Prinsip Pemasaran Jilid I. In Erlangga.

Kotler, P., \& Keller, K. L. (2009). Marketing management (13th ed.). In Prentice Hall.

Kotler, Philip. (2000). Marketing Management, Millenium Edition. Marketing Management. https://doi.org/10.1016/0024-6301(90)90145-T

Laurence, L., \& Mustamu, R. H. (2015). Manajemen Konflik dalam Perencanaan Suksesi Perusahaan Keluarga di Bidang Ekspedisi di Surabaya. Agora.

Lovelock, Wirtz, M. (2013). Pemasaran jasa. Journal of Chemical Information and Modeling. https://doi.org/10.1017/CBO9781107415324.004

Nasir, M., Faiz, M., \& Lee, M. (2011). Kepuasan pelanggan terhadap kualiti perkhidmatan di fakulti pendidikan teknikal dari aspek kemudahan dan fasiliti. Eprints.Uthm.Edu.My.

Rasyid, H. Al. (2017). Pengaruh Kualitas Layanan Dan Pemanfaatan Teknologi Terhadap Kepuasan Dan Loyalitas Pelanggan Go-Jek. Jurnal Ecodemica: Jurnal Ekonomi, Manajemen, Dan Bisnis. https://doi.org/10.31311/jeco.v1i2.2026

Safitri, E., Rahayu, M., \& Indrawati, N. K. (2016). Pengaruh Kualitas Pelayanan Dan Citra Perusahaan Terhadap Kepuasan Pelanggan Dan Loyalitas Pelanggan Service Center [Studi Pada Pelanggan Samsung Service Center Di Kota Malang. Ekonomi Bisnis.

Sanjaya, W. (2008). Kurikulum Dan Pembelajaran (Teori \& Praktek KTSP).

Sanjaya, W. (2010). Strategi Pembelajaran Berorientasi Standar Proses Pendidikan. System.

Sanjaya, W. (2015). Perencanaan dan Desain Sistem Pembelajaran. Kencana,Prenadamedia Group.

Sofyan, Y., Haris, H., Akib, H., Gani, H. A., \& Nuralim, M. (2018). Cooperative Establishment Service System in the Cooperative Office and Small and Medium Enterprises (UKM) Makassar City. 1st International Conference on Social Sciences (ICSS 2018). Atlantis Press.

Sutisna. (2003). Perilaku Konsumen: Teori dan penerapannya dalam Pemasaran. Ghalia Indonesia, Jakarta. https://doi.org/10.1007/BF01013984

Syam, H., Lamangida, T., Madubun, J., \& Akib, H. (2018). Public entrepreneurship perspective 
in management of the limboto lake in gorontalo regency, Indonesia. Academy of Entrepreneurship Journal, 24(4), 1-10.

Tjiptono, F., \& Chandra, G. (2011). Service, Quality \& Satisfaction. In Edisi 4. https://doi.org/10.3389/fgene.2015.00293

Uno, H. H. B. (2010). Model pembelajaran: menciptakan proses belajar mengajar yang kreatif dan efektif. In Jakarta: Bumi Aksara. https://doi.org/10.1038/cddis.2011.1 
38 | Jurnal Administrare: Jurnal Pemikiran Ilmiah dan Pendidikan Administrasi Perkantoran Vol. 7, No. 1, January-June 2020, Pages 29-38 